\title{
HUBUNGAN STATUS GIZI DENGAN PERKEMBANGAN ANAK USIA 3-5 TAHUN DI PENDIDIKAN ANAK USIA DINI (PAUD) MIDANUTTA'LIM DESA MAYANGAN KECAMATAN JOGOROTO KABUPATEN JOMBANG
}

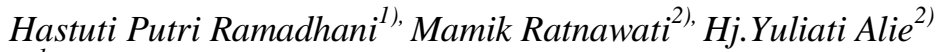 \\ ${ }^{1}$ Program Studi Sarjana Keperawatan Stikes Pemkab Jombang \\ ${ }_{2}^{2}$ Program Studi Diploma III Keperawatan Stikes Pemkab Jombang \\ email : putri.llahfie@gmail.com
}

\begin{abstract}
Nutrition is one determinant the quality of human resources, because undernourished will might cause failure growth and development on child. On child a preschool are the group that need attention will the nutrition, as they are in the growth and development. More than $50 \%$ of the children was suffering from a development. The purpose of research to know nutritional status of relations with children growth a preschool age 3 to 5 years in Midanutta'lim Mayangan Village Subdistrict Jogoroto District Jombang. Method : The research use analytic correlation design with cross sectional approached. Population is all children aged 3 to 5 years in PAUD Midanutta'lim Mayangan Village Subdistrict Jogoroto District Jombang with 70 children, the sample as many as 35 children. Technique sampling used purposive sampling, the independent variable is status nutrition and dependent variable is the development of baby a preschool age 3 to 5 years. An instrument use Z-scor and KPSP. Data mixed with editing, coding, scoring, tabulating, analysis data using the spearman rank. Result and discussion : Based on the research done got that the majority of respondents (74.3\%) a nutritional status of good, most respondents (68.6\%) undergo development children appropriate, test results spearman rank got that $\alpha$ count smaller than $\alpha$ table that 0,001 $<0,05$ which means $H 1$ received and value correlation coefficient 0,557. The conclusion are powerful relationship between nutritional status of children growth preschool age 3 to 5 years .

Based on the results of research is expected parents paying more attention to the nutritional intake in children especially at the age of a preschool because in this day and age that are the group vulnerable to nutrition problems will have an influence to the development of the baby.

Keywords : nutrition status, development, children aged 3-5 year
\end{abstract}

ABSTRAK: Gizi merupakan salah satu penentu kualitas sumber daya manusia, karena kurang gizi akan dapat menyebabkan kegagalan pertumbuhan dan perkembangan pada anak. Pada anak prasekolah merupakan kelompok yang perlu diperhatikan akan kebutuhan gizinya, karena mereka dalam masa pertumbuhan dan perkembangan. Lebih dari 50\% anak mengalami gangguan perkembangan. Tujuan penelitian untuk mengetahui hubungan status gizi dengan perkembangan anak usia 3-5 tahun di PAUD Midanutta'lim Desa Mayangan Kecamatan Jogoroto Kabupaten Jombang. Metode : Desain penelitian menggunakan analitik korelasi dengan pendekatan cross sectional. Populasi adalah semua anak usia 3-5 tahun di PAUD Midanutta'lim Desa Mayangan Kecamatan Jogoroto Kabupaten Jombang sebanyak 70 anak, dengan jumlah sampel 35 anak. Teknik sampling yang digunakan dengan purposive sampling, variabel independen adalah status gizi dan variabel dependen adalah perkembangan anak usia 3-5 tahun. Instrumen menggunakan z-scor dan KPSP, analisa data menggunakan Spearman Rank. Hasil pembahasan : Berdasarkan hasil penelitian didapatkan bahwa sebagian besar responden $(74,3 \%)$ mempunyai status gizi baik, sebagian besar responden $(68,6 \%)$ mengalami perkembangan anak yang sesuai, hasil uji spearman rank didapatkan bahwa $\alpha$ hitung lebih kecil dari $\alpha$ tabel yaitu $0,001<0,05$ yang artinya H1 diterima dan nilai correlation coefficient sebesar 0,557 . Kesimpulan bahwa ada hubungan yang sedang antara status gizi dengan perkembangan anak usia 3-5 tahun. Berdasarkan hasil penelitian diharapkan orang tua lebih memperhatikan asupan gizi pada anak khususnya pada usia prasekolah karena pada masa ini merupakan kelompok rawan terhadap masalah gizi yang akan berpengaruh terhadap perkembangan anak.

Kata kunci: $\quad$ Status Gizi, Perkembangan, Anak Usia 3-5 Tahun

\section{Pendahuluan}

Tumbuh kembang merupakan proses yang berkesinambungan yang terjadi sejak konsepsi dan terus berlangsung sampai dewasa. Dalam proses mencapai dewasa inilah, anak harus melalui berbagai tahap tumbuh kembang. Tercapainya tumbuh kembang optimal tergantung pada potensi biologik. Tingkat tercapainya potensi biologik seseorang merupakan hasil interaksi antara faktor genetik dan lingkungan bio-fisiko-psikososial (biologis, fisik dan psikososial). Proses yang unik dan hasil akhir yang berbeda- 
beda memberikan ciri tersendiri pada setiap anak (Soetjiningsih, 2015).

Masa usia prasekolah merupakan masa emas, dimana perkembangan seorang anak akan banyak mengalami perubahan yang sangat berarti. Pada masa usia prasekolah anak akan banyak mengalami masa peka, yang diartikan sebagai suatu masa dimana suatu fungsi berkembang demikian baiknya dan karena harus dilayani serta diberi kesempatan sebaikbaiknya. Agar masa usia prasekolah dapat optimal maka stimulasi pendidikan diperlukan guna memberikan rangsangan terhadap seluruh aspek perkembangan anak.

Data penyimpangan tumbuh kembang yang diperoleh diperkirakan lebih dari 200 juta anak balita gagal mencapai potensi perkembangan optimalnya karena masalah kemiskinan, malnutrisi, atau lingkungan yang tidak mendukung sehingga mempengaruhi perkembangan kognitif, motorik, emosi, dan sosial anak. Jumlah balita yang mencapai $10 \%$ dari penduduk Indonesia, menjadikan tumbuh kembang balita ini sangat penting untuk diperhatikan karena menyangkut kualitas generasi masa depan bangsa (Kementrian Kesehatan RI, 2012).

Pada tahun 2012, Kementerian Kesehatan Indonesia menemukan 57 $(11,9 \%)$ kasus kelainan tumbuh kembang, keterlambatan perkembangan hanya di satu ranah perkembangan saja, atau dapat pula lebih dari satu ranah perkembangan. Sekitar 5-10\% anak diperkirakan mengalami keterlambatan perkembangan. Data angka kejadian keterlambatan perkembangan umum belum diketahui dengan pasti, namun diperkirakan sekitar $1-3 \%$ anak di bawah usia 5 tahun mengalami keterlambatan perkembangan umum (IDAI, 2013).

Dari data Dinas Kesehatan Kabupaten Jombang yang mengalami gangguan perkembangan terbanyak ketiga yaitu di wilayah kerja Puskesmas
Gambiran sebanyak 51,53\% kasus, yang kedua di wilayah kerja Puskesmas Cukir sebanyak 54,93\% kasus, dan yang paling banyak yaitu di wilayah kerja puskesmas Mayangan sebanyak 55,51\% kasus (Dinas Kesehatan Jombang, 2015). Salah satu penyebab gangguan tumbuh kembang balita adalah kurangnya stimulasi, karena dapat menyebabkan penyimpangan tumbuh kembang anak bahkan gangguan yang menetap (Dinas Kesehatan Jombang, 2011).

Hasil penelitian yang dilakukan oleh Lindawati pada tahun 2013, menemukan persentase anak prasekolah yang mengalami ketidaksesuaian dalam tumbuh kembangnya masih dibawah persentase anak prasekolah yang mempunyai tumbuh kembang sesuai dengan usia. Persentase dari 76 anak yang menjadi responden penelitian didapatkan jumlah anak yang mengalami ketidaksesuaian dalam kembang cukup besar yaitu $31 \%$. Status gizi berhubungan signifikan dengan perkembangan motorik anak usia prasekolah. Status gizi yang kurang berpotensi untuk terjadi perkembangan yang tidak sesuai dengan usia. Studi pendahuluan yang di lakukan peneliti di PAUD Midanutta'lim Mayangan Jogoroto Jombang dari 10 responden didapat 6 dari responden perkembangannya meragukan pada anak yang berstatus gizi kurang4, gizi baik 2 dan 4 responden lainnya dengan perkembangan sesuai pada status gizi yang normal.

Dampak dari seringnya kita mengajari anak-anak menggambar apa saja yang dia temukan, maka kemampuankemampuan dan rasa percaya dirinya akan semakin berkembang. Stimulasi yang kita berikan juga diarahkan untuk kesiapannya masuk sekolah.Dengan mengasah kemampuan anak secara terus $\mathrm{s}$ menerus kemampuan anak akan semakin meningkat. Pemberian stimulasi dapat dengan cara latihan dan bermain. Anak yang mendapat stimulasi terarah akan lebih 
cepat berkembang dibandingkan anak yang kurang mendapat stimulasi (Raharjo, 2012). Hal ini dilakukan untuk menghilangkan ekspresi negatif anak pada saat bertemu orang lain atau sesuatu yang lain yang belum dikenalnya. Rangsangan ini dapat dilakukan di rumah (oleh orang tua, pengasuh dan keluarga lainnya). Dapat pula dilakukan dikelompok bermain (Play Group), taman kanak-kanak atau sejenisnya (Nursalam, Rekawati, 2006).

Upaya yang dilakukan agar anak tidak mengalami keterlambatan perkembangan adalah mendorong anak untuk meningkatkan kemampuannya sesering mungkin seperti melatih untuk berbicara dengan mengajak berbicara sesering mungkin, pada perkembangan motorik diperlukan stimulasi yang terarah dengan cara mengajak bermain, mengajari anak untuk olahraga yang teratur. Misalnya melempar atau menangkap bola, melompat-lompat atau main tali. Agar anak selalu aktif dalam bermain, yang harus diperhatikan adalah menjaga anak agar tidak terjadi cedera pada saat anak bermain atau melakukan aktifitas (Soetjiningsih, 2012).

\section{Metode}

Metode penelitian analitik korelasional dengan pendekatan Cross Sectional. Variabel independen adalah status gizi dan variabel dependen adalah perkembangan anak usia 35 tahun. Populasi pasien sebanyak 70 orang dengan sampel sebanyak 35 responden. Metode pengambilan sampel menggunakan teknik Purposive Sampling. Karakteristik responden dalam penelitian ini adalah anak usia 3 - 5 tahun laki-laki atau perempuan, anak yang kooperatif dan bersedia diteliti.

Waktu penelitian tanggal $3-6$ Juni 2016, tempat penelitian di PAUD Midanutta'lim desa Mayangan kecamatan Jogoroto kabupaten Jombang.

Instrumen yang digunakan adalah ZScor dan KPSP. Data dianalisa menggunakan uji korelasi Spearman Rank dengan tingkat kemaknaan $p<\alpha(0,05)$.
Hasil

Tabel 1 Distribusi frekuensi responden berdasarkan jenis kelamin

\begin{tabular}{lcc}
\hline Jenis kelamin & Frekuensi & Prosentase \\
\hline Laki-laki & 13 & 37,1 \\
Perempuan & 22 & 62,9 \\
\hline Total & 35 & 100
\end{tabular}

Sumber: Data primer, 2016

Tabel 2 Distribusi frekuensi responden berdasarkan pendidikan ibu

\begin{tabular}{lcc}
\hline Jenis kelamin & Frekuensi & Prosentase \\
\hline Dasar & 11 & 31,4 \\
Menengah & 20 & 57,2 \\
Tinggi & 4 & 11,4 \\
\hline Total & 35 & 100 \\
\hline
\end{tabular}

Sumber: Data primer, 2016

Tabel 3 Distribusi frekuensi responden berdasarkan jumlah anak dalam keluarga

\begin{tabular}{lcc}
\hline Jenis kelamin & Frekuensi & Prosentase \\
\hline 1 & 8 & 22,9 \\
$2-4$ & 23 & 65,7 \\
$>4$ & 4 & 11,4 \\
\hline Total & 35 & 100
\end{tabular}

Sumber: Data primer, 2016

Tabel 4 Distribusi frekuensi responden berdasarkan status gizi dalam keluarga

\begin{tabular}{lcc}
\hline Jenis kelamin & Frekuensi & Prosentase \\
\hline Buruk & 1 & 2,9 \\
Kurang & 8 & 22,9 \\
Baik & 26 & 74,3 \\
\hline Total & 35 & 100 \\
\hline
\end{tabular}

Sumber: Data primer, 2016

Tabel 5 Distribusi frekuensi responden berdasarkan perkembangan anak dalam keluarga

\begin{tabular}{lcc}
\hline Jenis kelamin & Frekuensi & Prosentase \\
\hline Sesuai & 24 & 68,6 \\
Meragukan & 11 & 31,4 \\
\hline Total & 35 & 100 \\
\hline
\end{tabular}

Sumber: Data primer, 2016 
Tabel 6 Tabulasi silang antara status gizi dan perkembangan anak

\begin{tabular}{llllllllll}
\hline \multirow{2}{*}{ Perkembangan } & \multicolumn{4}{c}{ Buruk } & \multicolumn{2}{c}{ Kurang } & \multicolumn{2}{c}{ Baik } & \multicolumn{3}{c}{ Total } \\
& f & $\%$ & f & $\%$ & f & $\%$ & f & $\%$ \\
\hline Sesuai & 1 & 2,9 & 1 & 2,9 & 22 & 62,9 & 24 & 100 \\
Meragukan & 0 & 0 & 7 & 20 & 4 & 11,4 & 11 & 100 \\
\hline Total & 1 & 2,9 & 8 & 22,9 & 26 & 74,3 & 35 & 100 \\
\hline
\end{tabular}

Sumber: Data primer, 2016

\section{Pembahasan}

Hasil penelitian mengatakan bahwa sebagian besar status gizi anak baik sejumlah 26 anak (74,3\%).

Status gizi adalah keadaan tubuh yang merupakan hasil akhir dari keseimbangan antara zat gizi yang masuk ke dalam tubuh dan penggunaannya (Cakrawati \& Mustika, 2012). Status gizi adalah ekspresi dari keadaan keseimbangan dalam bentuk variabel tertentu, atau perwujudan dari nutriture dalam bentuk variabel tertentu (Supriasa $\mathrm{dkk}, 2012$ ).

Tingkat pendidikan seseorang akan berkaitan erat dengan wawasan pengetahuan mengenai sumber gizi dan jenis makanan yang baik untuk konsumsi keluarga (Niehof, 1988 dalam Suhaimi A., 2006). Ibu rumah tangga yang berpendidikan akan cenderung memilih makanan yang lebih baik dalam mutu dan jumlahnya, dibandingkan dengan ibu yang pendidikannya lebih rendah (Khumaidi, 1992 dalam Marsigit W., 2004).

Dalam keluarga dengan anak yang terlalu banyak akan sulit untuk diurus, sehingga suasana kurang tenang dan dapat memengaruhi ketenangan jiwa anak. Suasana demikian secara tidak langsung akan menurunkan nafsu makan bagi anak yang terlalu peka terhadap suasana yang kurang menyenangkan.Kasus balita gizi kurang banyak ditemukan pada keluarga dengan jumlah anggota keluarga yang besar dibandingkan keluarga kecil. Jumlah keluarga memang menentukan status gizi, tetapi status gizi juga ditentukan oleh faktor lain seperti dukungan keluarga itu dalam pemberian makanan bergizi, dan pendapatan (Sajogyo, 1986 dan Berg, 1987 dalam Andriani dan Wirjatmadi, 2014).

Hal ini membuat peneliti berasumsi bahwa gizi pada anak sangatlah penting untuk memenuhi kebutuhan tubuh, asupan yang baik akan membuat status gizi anakpun baik sehingga diperlukan pemantauan status gizi anak secara bertahap agar diperoleh pertumbuhan dan perkembangan anak yang sesuai. Ada beberapa faktor lain yang mempengaruhi status gizi pada anak, seperti pendidikan orangtua. Pendidikan seseorang akan mempengaruhi kualitas derajat kesehatannya. Baik kesehatan dirinya maupun kesehatan orang disekitarnya. Seorang ibu yang berpendidikan cenderung bijak dalam memilah kebutuhan kehidupan terutama untuk kebutuhan anak. Karena ibu yang memiliki pendidikan menengah tentu akan memberikan yang terbaik terutama tentang asupan makanan untuk anaknya sesuai pengetahuan dan informasi yang ia dapatkan.

Hasil penelitian mengatakan bahwa sebagian besar perkembangan anak sesuai sejumlah 24 anak $(68,6 \%)$.

Perkembangan adalah bertambahnya kemampuan (skill) struktur dan fungsi tubuh yang lebih kompleks, dalam pola yang teratur dan dapat diramalkan, sebagai hasil dari proses pematangan/maturitas. Perkembangan menyangkut proses diferensiasi sel tubuh, jaringan tubuh, organ dan sistem organ yang berkembang sedemikian rupa sehingga masing-masing dapat memenuhi fungsinya. Termasuk juga perkembangan kognitif, bahasa, motorik, emosi dan perkembangan perilaku sebagai hasil dari interaksi dengan lingkungannya. Perkembangan merupakan perubahan yang bersifat progresif, terarah dan terpadu/koheren (Soetjiningsih, 2015).

Perkembangan merupakan hasil interaksi antara kematangan susunan saraf pusat dengan organ yang dipengaruhinya (Ambarwati \& Nasution, 2012). Sehingga 
perkembangan ini berperan penting dalam kehidupan manusia. Perkembangan dapat dilihat dari bertambahnya kemampuan dalam struktur dan fungsi tubuh yang lebih kompleks dalam pola yang teratur dan dapat diramalkan, sebagai hasil dari proses pematangan (Adriana, 2013).

Hal ini membuat peneliti berasumsi bahwa dengan perhatian lebih dari orang tua mengenai pertumbuhan dan perkembangan pada anaknya maka akan menghasilkan perkembangan yang sesuai. Perkembangan pada anak dapat dinilai dengan menggunakan Kuesioner Pra Skrining Perkembangan yang sesuai dengan umur anak. Tahapan-tahapan perkembangan yang dilalui anak akan menjadikan anak tersebut matang dalam perkembangan motorik kasar, motorik halus, bahasa dan kemandirian.

Hasil penelitian mengatakan bahwa sebagian besar status gizi anak baik mengalami perkembangan yang sesuai sebanyak 22 responden $(62,9 \%)$.

Nutrisi adalah termasuk pembangun tubuh yang mempunyai pengaruh terhadap pertumbuhan dan perkembangan, terutama pada tahun-tahun pertama kehidupan dimana anak sedang mengalami pertumbuhan yang sangat pesat terutama otak. Keberhasilan perkembangan anak ditentukan oleh keberhasilan pertumbuhan dan perkembangan otak. Jadi dapat dikatakan bahwa nutrisi, selain mempengaruhi pertumbuhan juga mempengaruhi perkembangan otak. Nutrisi menjadi kebutuhan untuk menunjang perkembangan. Dalam nutrisi terdapat kebutuhan zat gizi yang diperlukan untuk perkembangan seperti protein, karbohidrat, lemak, mineral dan vitamin, dan air. Apabila kebutuhan nutrisi seseorang kurang terpenuhi, maka dapat menghambat perkembangan (Hidayat, 2008).

Adapun dari hasil penelitian ini menunjukkan bahwa anak dengan perkembangan yang sesuai memiliki status gizi yang baik. Menurut peneliti hal ini dikarenakan perkembangan terjadi bersamaan dengan perubahan pertumbuhan dan setiap pertumbuhan disertai dengan perubahan fungsi seperti peningkatan mental, ingatan, daya nalar, asosiasi dan lain-lain, sehingga dengan keadaan seperti ini status gizi yang dimiliki anak harus selalu tercukupi agar perkembangan anak tidak terganggu. Dalam penelitian ini terdapat beberapa faktor yang berhubungan dengan status gizi dan perkembangan anak salah satunya adalah pendidikan orangtua. Pendidikan terakhir yang dimiliki oleh orang tua dapat mempengaruhi perilaku ibu dalam memenuhi status gizi bagi perkembangan anaknya, selain itu pendidikan orang tua mempengaruhi bagaimana mereka mendapatkan dan mengolah informasi yang bermanfaat bagi anak seperti tentang pemberian asupan nutrisi yang baik bagi anak, cara pemantauan pertumbuhan dan perkembangan anaknya.

Perilaku ibu tentang pemberian asupan nutrisi dan perkembangan kepada anaknya menunjukkan respon tentang pentingnya status gizi yang baik serta perkembangan yang sesuai bagi anaknya. Hal ini sesuai dengan teori keperawatan yang dikemukakan oleh Lawrence Green tentang perilaku kesehatan. Dimana terdapat faktor-faktor yang yang mempengaruhi tingkat kesehatan seseorang atau masyarakat dan salah satu faktor yang mempengaruhi adalah perilaku dan gaya hidup.

Jadi, status gizi sangat berperan penting dalam perkembangan seorang anak, pemberian asupan makanan yang kurang akan membuat gizi anak kurang terpenuhi. Hal ini disebabkan karena kurangnya perhatian khusus dari orangtua terhadap gizi yang didapatkan oleh anak. Sehingga pemberian asupan nutrisi harus lengkap dan seimbang agar kesehatan anak terjaga dengan baik dan pertumbuhan serta perkembangannya pun akan optimal.

\section{Kesimpulan dan Saran}

Berdasarkan hasil penelitian tentang hubungan status gizi dengan 
perkembangan anak usia 3-5 tahun di Pendidikan Anak Usia Dini (PAUD) Midanutta'lim Desa Mayangan Kecamatan Jogoroto Kabupaten Jombang tahun 2016, diperoleh kesimpulan sebagai berikut : Sebagian besar anak usia 3-5 tahun berstatus gizi baik di PAUD Midanutta'lim Desa Mayangan Kecamatan Jogoroto Kabupaten Jombang. Sebagian besar anak usia 3-5 tahun mengalami perkembangan sesuai di PAUD Midanutta'lim Desa Mayangan Kecamatan Jogoroto Kabupaten Jombang. Ada hubungan antara status gizi dengan perkembangan anak usia 3-5 tahun di PAUD Midanutta'lim Desa Mayangan Kecamatan Jogoroto Kabupaten Jombang, yaitu semakin baik status gizi seorang anak maka perkembangan anakpun sesuai dengan tingkat signifikasi hubungan sedang.

Bagi keluarga yang mempunyai anak dengan status gizi yang baik dan perkembangan yang sesuai, hendaknya mempertahankan status gizi anak dan selalu melakukan penimbangan di posyandu terdekat untuk selalu memantau gizi anak dengan memberikan asupan makanan yang bergizi.

Bagi institusi pendidikan, peneliti mengharapkan bahwa hasil penelitian ini untuk menambahkan ilmu metodologi yang diaplikasikan pada pengambilan data saat penelitian dan menambahkan pengembangan ilmu keperawatan anak khususnya tentang perkembangan anak.

Bagi tenaga kesehatan, peneliti mengharapkan bahwa tenaga kesehatan diharapkan dapat mempertimbangkan dalam pemantauan perkembangan anak khususnya dalam upaya meningkatkan perkembangan anak.

\section{Referensi}

Adriana, Dian. 2013. Tumbuh Kembang Dan Terapi Bermain Pada Anak. Jakarta: Salemba Medika.

Ambarwati, Fitri Respati. Nita Nasution. 2012. Buku Pintar Asuhan
Keperawatan Bayi Dan Balita. Yogyakarta: Cakrawala Ilmu

Andriani, M \& Wirjatmadi. 2014. Gizi Dan Kesehatan Balita. Jakarta : Kencana Prenada media Group.

Cakrawati, Mustika. 2012. Bahan Pangan, Gizi, dan Kesehatan. Bandung: Alfabeta.

Departemen Kesehatan Republik Indonesia. 2013. Profil Kesehatan Indonesia Error! Hyperlink reference not valid. tanggal 12 Desember 2015

Departemen Kesehatan Republik Indonesia, 2007. Riset Kesehatan Dasar. http://depkes.go.id.html

Dinas Kesehatan Jombang. 2011. Profil Kesehatan Kabupaten Jombang, dinkes.jombangkab.go.id.

Dinas Kesehatan Jombang. 2012. Profil Kesehatan Kabupaten Jombang, dinkes.jombangkab.go.id.

Dinas Kesehatan Jombang. 2014. Profil Kesehatan Kabupaten Jombang, dinkes.jombangkab.go.id.

Dinas Kesehatan Jombang. 2015. Profil Kesehatan Kabupaten Jombang, dinkes.jombangkab.go.id.

Hidayat, AA. 2012. Metode Penelitian Keperawatan dan Teknik Analisis Data. Jakarta. Salemba Medika.

IDAI. 2013. Sari Peditari - Hubungan Status Gizi dan Perkembangan Anak, sapipediatri.idai.or.id.

Kementerian Kesehatan Republik Indonesia. 2012. Publikasi data dan Informasi. www.depkes.go.id.

Keputusan Menteri Kesehatan Indonesia. 2010. Standar Antropometri Penilaian Status Gizi Anak.

Lindawati. 2013. Faktor-Faktor Berhubungan Dengan Perkembangan Motorik Usia Prasekolah. http://www.poltekesjakarta1.ac.id/ / diakses tanggal 30 November 2015 
Nursalam, Rekawati. 2006. Asuhan Keperawatan Bayi dan Anak, Jakarta : Salemba Medika.

Proverawati. 2010. Buku Ajar Gizi untuk Kebidanan. Jogjakarta: Nuha Medika.

Rahardjo, Kukuh. 2012. Asuhan Neonatus Bayi, Balita, dan Anak Prasekolah. Yogyakarta: Pustaka Pelajar.

Siswono. 2008. Gizi Buruk Berdampak Loss Generation. http//:Dampak Gizi-Buruk-Bagi-Anak-

Anak.html. Diakses 11 Maret 2016

Soetjiningsih. 2012.Tumbuh Kembang Anak. Jakarta: EGC.

Soetjiningsih, IG.N. Gde Ranuh. 2015. Tumbuh Kembang Anak Edisi 2. Jakarta: EGC.

Supriasa, dkk. 2012. Penilaian Status Gizi. Jakarta: EGC.

Sutarta. 2008. Pangan, Gizi, dan Pertanian. Jakarta : UI Pers.

Tanuwidjaya, Soetjiningsih, Narendra Moersintowati B, dkk. 2010. Tumbuh Kembang Anak Dan Remaja. Jakarta: Sagung Seto.

Wong, D. L. (2008). Pedoman klinis keperawatan pediatrik (wong and whaley's clinical manual of pediatric nursing). (4th ed). (Monica Eater \& Sari Kurnianingsih, Penerjemah). Jakarta: EGC

Yusuf, Syamsu. 2011. Psikologi Perkembangan Anak dan Remaja. Bandung: PT Remaja Rosdakarya. 